Lagertechnik und Organisation in Industrie und Handel. Ein Handbuch fuer das Management (Técnica de armazenagem e organização de estoques em indústria e comércio. Um manual para a gerência)

Por Dimitris Chorafas. Düsseldorf, Dreste Verlag, 1973, 157 p. de texto $+32 p$. de fotografias.

Os livros comuns sobre o sistema de armazenagem correspondem à classificação "técnicas de almoxarifado". A construção de almoxarifados no Brasil tem-se limitado, na sua concepção, até há poucos anos, a colocar estantes pré-fabricadas ou não para o uso manual, ou então estantes para colocação de estrados por meio de empiIhadeiras, que já são fabricadas no país. Outrossim, tornou-se comum um empilhamento de cestas especiais, por meio de empilhadeiras, até quatro ou seis metros de altura. A técnica de correlação do custo do $\mathrm{m}^{2}$ de área do piso do armazém com o número de $\mathrm{m}^{2}$ aproveitáveis está ainda no início. Com o encarecimento dos terrenos ficou evidente que a altura de empilhamento devia ultrapassar os quatro a cinco metros que uma empilhadeira fabricada atualmente no Brasil permite. As empilhadeiras para grandes alturas têm de ser programadas previamente, pois o olho humano não acerta mais a colocação de estrados a grandes alturas. Outra alternativa é a empilhadeira-elevador, na qual o homem sobe, com o estrado e o garfo, podendo até mesmo dirigir a empilhadeira de cima, a oito metros de altura. Também pode recolher as encomendas, à mão, lá em cima.

Há portanto um progresso constante na técnica de armazenagem. A construção civil não faz mais galpões, nem coloca dentro deles as estantes, como antigamente. As próprias estantes seguram o telhado, que não necessita de paredes ou colunas laterais de suporte, só de fechamento por chapas facilmente removíveis para ampliação.

Todos os fatos acima descritos estão no novo livro de Chorafas, professor universitário e consultor de muitas indústrias, tendo realizado o estudo para o livro na Alemanha, Suíça, Estados Unidos, Israel e França, com o auxílio de assistentes. A obra não fornece maiores detaIhes sobre a pessoa do autor e tem a grande falha de não apresentar bibliografia ou índice remissivo, nem mesmo há notas de rodapé. Mas isso classifica o livro como dirigido ao homem prático em vez de acadêmico. Ele é claro em informações sobre os procedimentos de escoIha baseado em custos.

O livro tem 12 capítulos:

1. Bases da armazenagem: objetivos, o armazém, exame das alternativas, descentralização e centralização. Sistemas de computação.

2. O depósito moderno, uma empresa distribuidora: suplementação do marketing-custos.

3. Um sistema de armazenamento e entrega. Bases, funda- mentos, objetivos, organização, falhas e a pesquisa de erros.

4. Construção de armazéns comuns.

5. Os meios de armazenagem - estrados, estantes. Organização, engarrafamentos.

6. O transporte. A carga e descarga. O porto.

7. Os novos sistemas - o depósito de estantes altas. Casos. Critérios.

8. Estantes altas e transporte interno contínuo - casos, problemas. A CIBA.

\section{Cálculos orçamentários.}

10. O computador na armazenagem. Cuidados com os sistemas. Planejamento.

11. Casos e problemas com o computador. Responsabilidade.

12. Os dados. Erros - precisão exigida. Integração. Caso da OSRAM GmbH. Fotografias dos capítulos.

Para mostrar a utilidade desta obra para o homem prático, o engenheiro, o gerente de construções, é possível citar:

A) A construção-padrão do almoxarifado, das p. 52 a 58 , dando medidas de chapas-padrão, largura de arcos conforme a altura, e tratando de parafusos e chapas de alumínio-padrão ilustrando essas informações com gravuras, todas elas infelizmente no fim do livro.

B) O almoxarifado com estantes elevadas, de altura acima de $6 m$ até $13 m$ é tratado por casos e discussão técnica e em quadros em mais de 25 p. começando na p. 81. Um excelente estudo de custos é apresentado na p. 88. Lamentavelmente não há um gráfico do ponto de equilíbrio entre o custo de construção e o do terreno, para comparar a construção de um almoxarifado com prateleiras acima de 
$6 \mathrm{~m}$ e aqueles com a altura "normal".

Seria necessário frisar aqui algo inexistente no livro: a manutenção mecânica de um almoxarifado de altas prateleiras é excessivamente cara, pois as empilhadeiras, em lugar de serem "máquinas a motor, elevadoras" são computadores, elevadores móveis, de equilíbrio perfeito, exigindo nivelamento de precisão superior a 1:1000 no piso do almoxarifado. Este, além disso, deve resistir a grandes esforços de brecagem, sem se abalizar.

Para mostrar a utilidade do livro para o homem de sistemas, o calculista dos procedimentos de administração de materiais, há longas dissertações sobre a pesquisa de erros (p. 48 e seg.), principalmente na OSRAM $\mathrm{GmbH}$, que possui também uma fábrica perto de São Paulo. Assim frisam-se as fontes de erros em três depósitos experimentais:

$$
\begin{aligned}
\mathrm{O}= & \begin{array}{l}
\text { origem (erro no número } \\
\text { da origem) }
\end{array} \\
\mathrm{S}= & \begin{array}{l}
\text { sufixo (erro no número } \\
\text { complementar) }
\end{array} \\
\mathrm{CB}= & \begin{array}{l}
\text { código-base (erro no nú- } \\
\text { mero de ordem) (base) }
\end{array}
\end{aligned}
$$

$\mathrm{C}=$ contagem (erro na contagem)

$\mathrm{NI}=$ não-identificado (erro não-esclarecido)

Outro ponto importante para a pessoa interessada na automação completa do sistema de armazenamento está na velocidade cle processamento e na leitura ótica para enquadramento automático na vaga certa da estante e a maneira de afixar a tira de cor para leitura ótica.

Quando trata do problema da velocidade de processamento exigido, mostra a realização de grandes economias processando eletronicamente apenas os pedidos que não podem ser imediatamente (e manualmente) atendidos pelos depósitos existentes.

Para realçar a utilidade da obra para o homem de custos é suficiente examinar o cap. 9, p. 109 a 121, dedicado ao orçamento do armazém que apresenta duas tabelas tiradas de casos práticos pesquisados.

Até mesmo o administrador por objetivos consegue encontrar no livro objetivos tais como "minimização do intervalo de tempo entre a entrada do pedido e a entrega da mercadoria", "remessa mais rápida de informações para a administração" ou ainda "maior eficiência da mão-de-obra em $\mathrm{t} / \mathrm{h} /$ pessoa processadas".

Um livro bom como este pode se dar ao luxo de ter alguns senões sem perder seu valor intrínseco. Assim a separação em duas partes - texto e gravuras no fim do livro, e estas ainda confusamente arranjadas - perturba o leitor. Tem a vantagem de permitir o uso de papel glacê para as gravuras, mas tal não é essencial.

De vez em quando o autor cai em preciosismo de transformação de unidades americanas em métricas - por exemplo, na p. 77 , diz que num porto a área de armazenamento de containers (cofres de carga) deve ser "aproximadamente 80,94 ha". O "aproximadamente" traria consigo "80 ha" mas em inglês provavelmente o autor encontrou square feet ou square yards como unidades.

Falta, e muito, um índice remissivo, e estranha-se a ausência - como também já foi mencionado - de um grupo de leituras paralelas, catálogos e textos de empresas distribuidoras de máquinas empilhadeiras e, finalmente, uma bibliografia teórica e prática completa.
Mas o livro preenche a falta de uma obra sobre armazenamento que é primordial em quase todas as empresas no mundo.

Kurt Weil 